\section{Genetic diversity and phylogenetic behavior of some minor legumes}

\author{
James Oludare Agbolade, Ronke Justina \\ Komolafe \\ Department of Plant Science and \\ Biotechnology, Federal University Oye- \\ Ekiti, Nigeria
}

\section{Abstract}

Twenty-four accessions of twelve species minor legumes collected from the germplasm unit of the International Institute of Tropical Agriculture Ibadan, Nigeria were evaluated for their genetic diversities and phylogenetic relatedness. The accessions were planted into plots of 5 ridges of 5 meters long, spaced 1 meter apart and replicated three times at the Federal University Oye-Ekiti Teaching and Research Farm. The diversity and the relative phylogeny of the accessions were assessed through their floral morphological differences and the mean values between two accessions were evaluated by descriptive statistics. Principal component analysis was employed to identify the most discriminatory floral morphological traits and the similarities among the 24 accessions were assessed by cluster analysis (CA). Descriptive statistics through Duncan multiple range test adopted revealed genetic diversity and phylogenetic relatedness among the accessions. The first two principal component axes explained $64.66 \%$ of the total floral morphological variation. Standard petal length, calyx lobe length and stipule length contributed most of the variations in the legume accession. CA grouped the 24 accessions into six clusters. The study revealed intra-specific similarities and inter-specific floral morphological differences among the studied accessions.

\section{Introduction}

All plants of the pea and bean family (leguminosae) are termed legumes. This composed of three major subfamilies viz; caesalpinaceae, mimosaceae and papillonacea, which are senna family, locust bean family and family of about ten tribes, respectively. ${ }^{1,2}$

The family of legume (leguminosae) is very large embracing a large group of dicotyledonous plants. Their fruits are in the form of pods, which may be round, flat, winged, straight or curve, and of varying lengths. The fruit may also be fibrous or fleshy and are often split open at maturity. They always have complete and irregular flowers. The flowers are usually hermaphroditic with calyx having five, more or less unequal and partially united sepals. ${ }^{2,3}$

Grain legume is a major component of grain-based farming system in many parts of the world. Grain legumes can be divided into two groups as major and minor species according to world economy and plant utility. ${ }^{4,5}$ The major ones are the industrial legumes such as soybean and groundnut. ${ }^{6}$

These major species are extremely important in the world economy. Others among the list are common beans (Phaseolusvulgaris), Chicken pea (Cicerarietanum) and pea (Pisumsativum). The minor species have a broad spectrum of diversity across various regions worldwide; existing either as cultivated or wild species. They are usually cultivated by traditional farmers. Examples of such minor species includes Kersting groundnut (Kerstingiella geocarpa), Marama bean (Tylosema esculentum). ${ }^{6,7}$ Consumption of legumes was also highly correlated with reduced mortality resulting from coronary heart diseases. ${ }^{5}$ Studies have also been carried out on the in vitro multienzyme digestibility of flower proteins of six varieties of African Yam Bean (AYB). ${ }^{7}$

Minor grains legumes could also be referred to as neglected, underutilized etc. ${ }^{8,9}$ The major legumes have attracted much research attentions unlike the minor ones. The long cooking period required for processing of the minor grain legumes for food, the bushy growth habit, long life cycle and extra efforts needed for their cultural field maintenance are factors militating against their cultivation and utilization. Production statistics' ratio of the minor legumes as compared with the major ones could be as low as one to hundred..$^{4,8,9}$ Plant floral characters have been indicated to reveal most discriminatory morphological traits among accessions. ${ }^{2}$

Minor legumes are rich sources of plant proteins in human diet, good sources of genetic factors and chemicals for insect pest resistance. Most of the representative minor legumes have potential to improve nutrition, boost food security, foster rural development and support sustainable land care. ${ }^{10}$

There is paucity of information on the phylogenetic behavior and the genetic diversity of the major representative minor legumes; for these reasons, this work is designed to establish data on the differences and similarities observed on floral morphology of twenty-four minor legume accessions with a view to a revealing their diagnostic features which could serve as a guide to their genetic diversity and relative phylogeny.
Correspondence: James Oludare Agbolade, Department of Plant Science and Biotechnology, Federal University Oye-Ekiti, Aare Afao Road, Oye-Ekiti, Ekiti, Nigeria.

E-mail: datus_oludare@yahoo.com

Key words: Accessions; Germplasm; Phylogenetic; Cluster analysis; Principal component analysis.

Contributions: the authors contributed equally.

Conflict of interest: the authors declare no potential conflict of interest.

Received for publication: 4 August 2015.

Revision received: 12 November 2015

Accepted for publication: 12 November 2015

This work is licensed under a Creative Commons Attribution-NonCommercial 4.0 International License (CC BY-NC 4.0).

(C) Copyright J. Oludare et al., 2016

Licensee PAGEPress srl, Italy

International Journal of Plant Biology 2016; 7:6136 doi:10.4081/pb.2016.6136

\section{Materials and Methods}

\section{Seed acquisition}

Seeds of twenty-four accessions of twelve species of miscellaneous legumes were obtained from the Genetic Resources Unit of the International Institute of Tropical Agriculture (IITA), Ibadan, Oyo-State, Nigeria for screening. The species studied are Bambara groundnut [Vigna subterranean (L.) Thouars] (TVSu 1126 and TVSu 1415), Green gram [Vignaradiata $(L$. R.Wilczek] (TVr 145 and TVr 1001), Jack bean (JB) [Canavalia ensiformis (L.) DC] (TCel and TCe3), Mung bean [Vignamungo (L.) Hepper] (TVm 12 and TVm 13), Pigeon pea [Cajanuscajan (L.) DC] (TCc 8127 and TCc8156), Rice bean [Vignaangularis (L.) Thouars] (TVa 1 and TVa 1173), AYB [Sphenostylisstenocarpa (HochstEx.A. Rich)] Harms (TSs 137 and TSs 156), Kersting groundnut [kerstingiellageocarpa (Harms)], (TKg 6 and TKg 12) lablab [Lablab purpureus (var. lignosus)] (TLn 21 and TLn 29), Mexican yam bean [Pachyrhizustuberosus (Lam.)] (TPtu 1 and TPtu 5), Sword bean (SB) [Canavaliangladiata (Jacq.) DC] (TCg 1 and $\mathrm{TCg} 4$ ) and Winged bean [Psophocarpustetragonolobus (L.) DC] (TPt 12 and TPt 18).

\section{Seed cultivation}

Seeds of the twenty-four accessions studied were planted on $5 \mathrm{~m}$ ridges, spaced $1 \mathrm{~m}$ apart at the teaching and Research Farm of the Federal University Oye-Ekiti, Ekiti State. Each accession was planted on two rows at $1 \mathrm{~m}$ intra-row spacing. Initially, two seeds were planted per hill and later thinned to one plant per hill, to 
give a total of twelve plants per accession per plot. Three replicates of the plot were prepared. The plants were sprayed at one-week interval with karate at a concentration of $0.5 \%$ starting from the period of flower bud initiation to pod maturity. The experimental plots were kept clean throughout the period of the study. Measurements were taken on quantitative vegetative characters such as terminal leaflet length and width, stipule length and width, petiole length and rachis length. Means of ten measurements taken from randomly selected plants for each accession were calculated and recorded.

\section{Floral character study}

The plants in each accession were scored for their qualitative floral characters (pattern of pigmentation on peduncle and flower color). Ten measurements were taken for each quantitative floral character from ten randomly picked flowers from plants in each accession. The means of the measurements were calculated and recorded. The quantitative floral characters measured include standard petal length and width, peduncle length and calyx lobe length.

\section{Data collection}

Data for floral morphological studies were generated from four individual plants within the row of each accession. Quantitative characters were determined by measurement and counting. The qualitative characters, which were determined visually, were scored by nominal codes. No descriptor had been developed for most miscellaneous legumes yet. Descriptors for cowpea were therefore used as guide to develop the descriptors list for the present morphological characterization. ${ }^{11}$

\section{Data analysis}

Duncan multiple range tests were employed to analyze the similarities and differences in the mean values of the quantitative characters. The multivariate statistical methods employed were Principal Component Analysis (PCA) and Cluster Analysis (CA). The PCA produced vector loadings for variables on principal component (PC) axes while CA produced a cluster grouping in the form of a Dendrogram. Pearson correlation coefficient was employed to identify the dependence of characters on one another for vegetative, floral as well as pod and seed characters.

\section{Results}

Observations made and data taken on the floral characters of the species and accessions studied are shown in Figures 1 and 2 and Table 1. Majority of the species possessed cleitogamous flowers, which open late in the evening or early in the morning and close before noon. Most of them also possessed irregular or zygomorphic flowers. AYB, SB and JB had calyx consisting five sepals and the corolla made up of a standard, two wings and two lower petals that lie inside the wings and are united at a lower margins to form a keel (platform). Nearly all the stamens of the miscellaneous legumes were diadelphous with nine bounded together forming a tube round the ovary while the tenth stamen is free producing yellow powdery pollen grains. Racemes inflorescence is very common among all having the older flowers at the base, opening before the younger flower at the tips (Figures 1 and 2). Twelve accessions produced yellowish flowers, seven produced lilac colored flowers, four purplish and one blue flower. This is as presented in Table 2.

Table 1 presents data on quantitative floral

Table 1. Mean values of six floral characters of the miscellaneous legumes.

\begin{tabular}{|c|c|c|c|c|c|c|c|c|}
\hline Scientific name & \multicolumn{3}{|c|}{ Common nameAccession numberSPL } & SPW & PDL & CLL & D50\%F & NFP \\
\hline Canavalia gladiate & Sword bean & TCg1 & $3.40^{\mathrm{i}}$ & $0.90 \mathrm{f}^{\mathrm{g}}$ & $30.63^{\mathrm{a}}$ & $2.05^{\mathrm{j}}$ & 56.00 & $3.20^{\mathrm{bc}}$ \\
\hline Canavalia gladiate & Sword bean & $\mathrm{TCg} 4$ & $2.60^{\mathrm{h}}$ & $0.90^{\mathrm{fg}}$ & $20.45^{\mathrm{h}}$ & $1.67^{\mathrm{g}}$ & 66.00 & $3.20^{\mathrm{bc}}$ \\
\hline Pachyrhizustuberosus & Mexican yam bean & TPtul & $1.79^{f}$ & $0.63^{\mathrm{bc}}$ & $17.86^{\mathrm{g}}$ & $1.02^{\mathrm{f}}$ & 57.00 & $5.30^{\mathrm{fg}}$ \\
\hline Pachyrhizustuberosus & Mexican yam bean & TPtu5 & $1.80^{\mathrm{f}}$ & $0.66 \mathrm{~b}^{\mathrm{c}}$ & $17.89^{\mathrm{g}}$ & $1.04^{\mathrm{f}}$ & 57.00 & $5.30^{\mathrm{fg}}$ \\
\hline Psophocarpustetragonolobus & Winged bean & TPt12 & $2.56^{\mathrm{g}}$ & $1.40^{\mathrm{i}}$ & $17.76^{\mathrm{g}}$ & $1.07^{\mathrm{f}}$ & 63.00 & $13.30^{\mathrm{i}}$ \\
\hline Psophocarpustetragonolobus & Winged bean & TPt18 & $1.88^{f}$ & $0.65^{\mathrm{bc}}$ & $18.13^{\mathrm{g}}$ & $1.03^{\mathrm{f}}$ & 45.00 & $14.10^{\mathrm{j}}$ \\
\hline Canavalia ensiforms & Jack bean & TCcl & $1.64^{\mathrm{e}}$ & $0.80^{\text {ef }}$ & $23.12^{\mathrm{i}}$ & $1.26^{\mathrm{g}}$ & 63.00 & $5.30^{\mathrm{fg}}$ \\
\hline Canavalia ensiforms & Jack bean & TCc3 & $2.62^{\mathrm{h}}$ & $0.89^{\text {fg }}$ & $23.23^{\mathrm{i}}$ & $1.52^{\mathrm{h}}$ & 70.00 & $3.70^{\text {cd }}$ \\
\hline Vignaangularis & Rice bean & TVal & $2.58^{\mathrm{h}}$ & $1.39^{\mathrm{i}}$ & $12.87^{\mathrm{cd}}$ & $1.07^{\mathrm{f}}$ & 66.00 & $3.80^{\mathrm{d}}$ \\
\hline Vignaangularis & Rice bean & TVall73 & $1.20^{\mathrm{b}}$ & $1.07^{\mathrm{h}}$ & $12.90^{\mathrm{cd}}$ & $0.82^{\text {cde }}$ & 125.00 & $3.80^{\mathrm{d}}$ \\
\hline Vignamungo & Mung bean & TVm12 & $1.34^{c}$ & $0.73^{\text {cde }}$ & $12.06^{\mathrm{bc}}$ & $1.03^{\mathrm{f}}$ & 43.00 & $5.70^{g}$ \\
\hline Vignamungo & Mung bean & TVm13 & $1.56^{\mathrm{de}}$ & $0.78^{\mathrm{de}}$ & $11.45^{b}$ & $0.96^{\mathrm{ef}}$ & 42.00 & $2.80^{\mathrm{b}}$ \\
\hline Lablab purpureus & Lablab bean & TLn21 & $1.56^{\mathrm{de}}$ & $0.40^{\mathrm{a}}$ & $22.01^{\mathrm{i}}$ & $0.80^{\mathrm{cd}}$ & 57.00 & $3.50^{\text {cd }}$ \\
\hline Lablab purpureus & Lablab bean & TLn29 & $1.64^{\mathrm{e}}$ & $0.40^{\mathrm{a}}$ & $21.93^{\mathrm{i}}$ & $0.77^{\mathrm{c}}$ & 57.00 & $8.80^{\mathrm{h}}$ \\
\hline Sphenostylisstenocarpa & African yam bean & TSs 137 & $2.11^{\mathrm{g}}$ & $0.93^{g}$ & $18.13^{g}$ & $0.71^{\mathrm{c}}$ & 84.00 & $14.50^{\mathrm{jk}}$ \\
\hline Sphenostylisstenocarpa & African yam bean & TSs156 & $2.62^{\mathrm{h}}$ & $1.11^{\mathrm{h}}$ & $16.18^{f}$ & $0.81^{\text {cd }}$ & 83.00 & $15.00^{\mathrm{k}}$ \\
\hline Vigna subterranean & Bambara groundnut & TVsul126 & $0.72^{\mathrm{a}}$ & $0.30^{\mathrm{a}}$ & $4.09^{\mathrm{a}}$ & $0.20^{\mathrm{a}}$ & 55.00 & $1.80^{\mathrm{a}}$ \\
\hline Vigna subterranean & Bambara groundnut & TVsu1415 & $0.73^{\mathrm{a}}$ & $0.30^{\mathrm{a}}$ & $4.05^{\mathrm{a}}$ & $0.19^{\mathrm{a}}$ & 55.00 & $1.80^{\mathrm{a}}$ \\
\hline Kerstingiellageocarpa & Kersting groundnut & TKg6 & $0.76^{\mathrm{a}}$ & $0.30^{\mathrm{a}}$ & $3.96^{\mathrm{a}}$ & $0.22^{\mathrm{a}}$ & 20.00 & $1.80^{\mathrm{a}}$ \\
\hline Kerstingiellageocarpa & Kersting groundnut & TKg12 & $0.76^{\mathrm{a}}$ & $0.30^{\mathrm{a}}$ & $3.99^{\mathrm{a}}$ & $0.20^{\mathrm{a}}$ & 20.00 & $1.90^{\mathrm{a}}$ \\
\hline Vigna radiate & Green gram & TVr45 & $1.35^{\mathrm{c}}$ & $0.59^{\mathrm{b}}$ & $13.81^{\mathrm{de}}$ & $0.50^{\mathrm{b}}$ & 75.00 & $4.80^{\mathrm{ef}}$ \\
\hline Vigna radiate & Green gram & TVr1001 & $1.48^{\mathrm{d}}$ & $0.68^{\mathrm{bcd}}$ & $14.26^{\mathrm{e}}$ & $0.50^{\mathrm{b}}$ & 41.00 & $4.60^{\mathrm{e}}$ \\
\hline Cajanuscajan & Pigeon pea & TCc8127 & $1.58^{\text {de }}$ & $0.79^{\text {def }}$ & $20.16^{\mathrm{h}}$ & $0.93^{\text {def }}$ & 80.00 & $1.90^{\mathrm{a}}$ \\
\hline Cajanuscajan & Pigeon pea & ТCc8156 & $1.57^{\mathrm{de}}$ & $0.72^{\text {cde }}$ & $20.04^{\mathrm{h}}$ & $0.98^{f}$ & 78.00 & $2.00^{\mathrm{a}}$ \\
\hline Total mean & & & 1.74 & 0.73 & 15.84 & 0.89 & 60.75 & 5.50 \\
\hline
\end{tabular}

SPL, Standard petal length; SPW, Standard petal width; PDL, Peduncle length; CLL, Calyx lobe length; NFP, Number of flower per peduncle; D50\%F days to 50\% flowering. a,b,c,de,f,g,h,i,ifferent letters in the same row denote significant differences among parameters. 
characters of the miscellaneous legumes. AYB, Lablab bean, SB, JB, Pigeon pea, Winged bean were highly prolific in flower production. However, a large number of the flowers were aborted and dropped without developing into fruit. The two accessions of TSs (156 and 137) produced the highest number (15.00 and 14.50) of flowers per peduncle respectively while TVsu1126, TVsu1415 and TKg6 had the least (1.80). Standard petal length ranged between 3.40 in TCg1 to 0.72 in TVsu1126 while standard petal width ranged from 1.40 in TPt12 and 0.30 both in the two accessions of TVsu (1126 and1415) and TKg (6 and 12). The two accessions of each of the twelve species of the miscellaneous legumes displayed similarities in their floral characters. This is however with the exception of TCg1 and TCg4, TPt12 and TPt18, TCc1 and TCc3, TVal and TVa1173 which showed significant differences in standard petal length. TPt12 and TPt18 also showed significant differences in their standard petal width. TCc1 and TCc3, TVm12 and TVm13, TLn21 and TLn29 were remarkably different in the number of flowers per peduncle.

\section{Principal component analysis}

The Eigen values, variance proportion of five PC axes and the Eigen vectors of five floral morphological traits are presented in Table 2. Although, five PC axes were identified by the PCA, only two had Eigen value greater than or equal to 1.0. The percentage variances reduced progressively from PC1 to PC5. The percentages of the total variance within the first two PC-axes were 64.66 and 20.19 respectively. The Eigen value for each of the first two PC-axes was greater than 2.5 and this explained $64.66 \%$ of the total variation. In the table, floral morphological traits with Eigen vector greater than or equal to 0.2 were significant in their contribution to loading each PC-axis. All the five floral characters from standard petal length, standard petal width, peduncle length, calyx lobe length to number of flower per peduncle loaded PC 1. Two out of these characters in PC1 re-

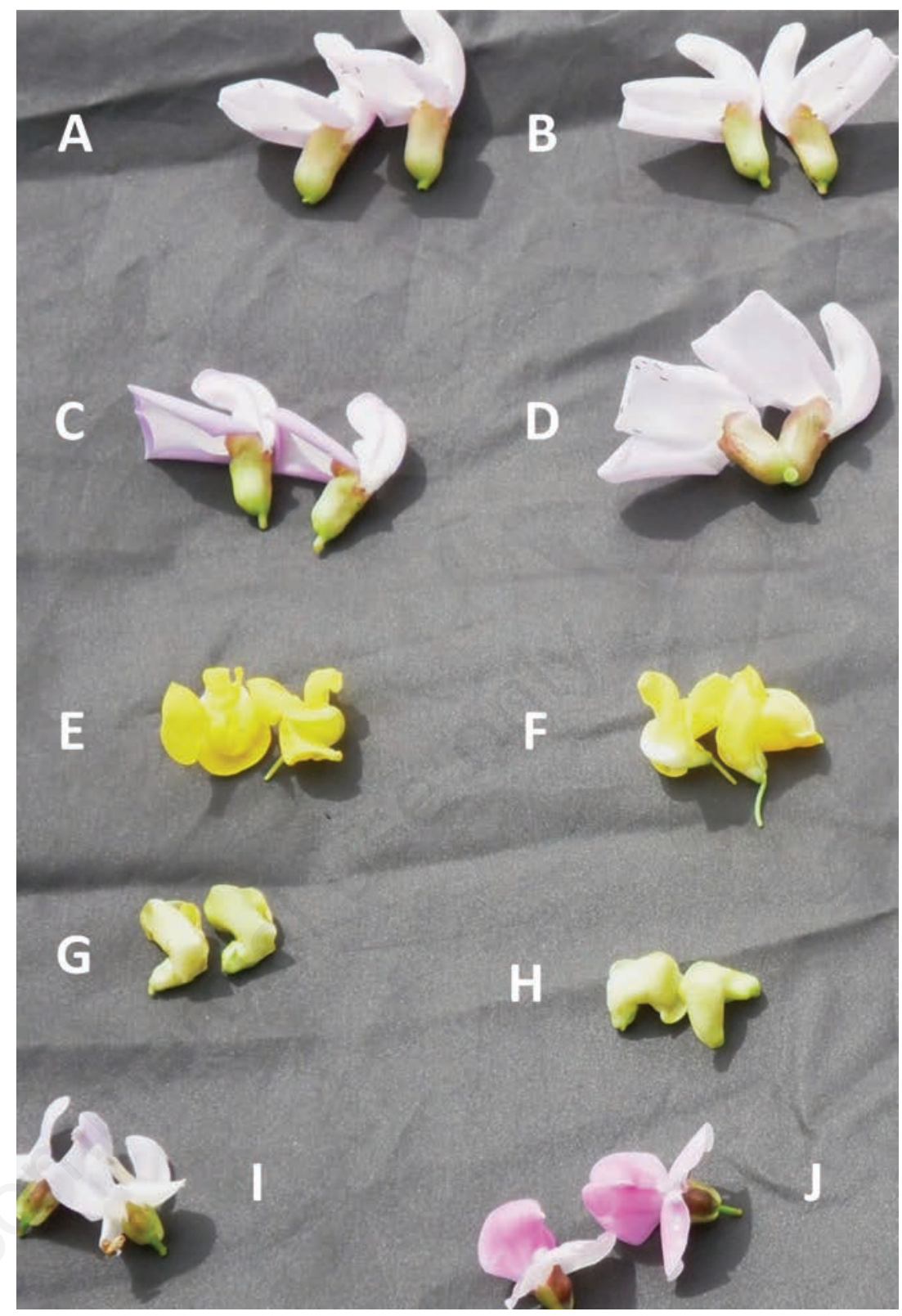

Figure 1. Flower colour of some of the miscellaneous legumes. A) TCg1, sword bean; B) TCg4, sword bean; C) TCe1, jack bean; D) TCe3, jack bean; E) TVa1, rice bean; F) TVa1173, rice bean; G) TVm12, mung bean; H) TVm13, mung bean; I) TLh21, lablab bean; J) TLn29, lablab bean.

Table 2. Eigen values, variance proportion of five pc-axes and eigen vectors of five floral morphological characters.

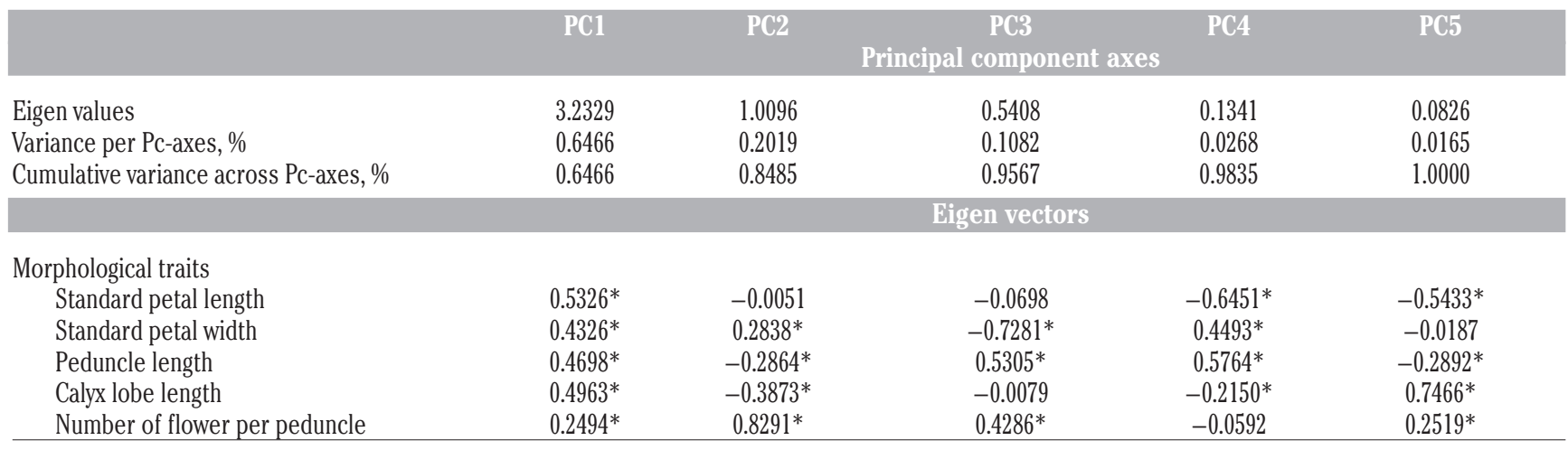

\footnotetext{
*Eigen vectors $\geq 0.2$
} 
featured in PC2 making positive contribution to total variation in the 24 legume accessions.

\section{Cluster analysis}

The two dimensional spatial configuration of 24 accessions of the miscellaneous legumes based on their floral characters is presented in Figure 3. The configuration explained almost $85 \%$ of the total variation among the species and accessions. Six distinct sub-specific clusters could be delimited among the taxa. Accessions coded 21, 22 (TV 145 and TVr1001), 9, 10 (TVal and TVa1173), all bearing the same generic nomenclature fell within a cluster and also in association with one accession of Lablab purpureus (TLn29 coded 14). This was similar to occurrence in vegetative morphological character. Three out of the four accessions of the genus Canavalia formed a separate cluster (coded 2, 8 and 1). Accessions coded 2 and 8 of the species Canavalia gladiata and Canavalia ensiformis appeared to be more closely related based on their floral morphology. Table 3 shows the cluster history of the 24 accessions of the miscellaneous legumes based on their floral characters. The analysis produced 23 morphotypes just as observed in vegetative morphological analysis. Accessions TVsul126 and TVsu1415 were the most similar phenotype based on the five floral characteristics employed to discriminate among the 24 accessions as both had the least distance of 0.0042. Diversity of the 24 accessions spanned a distance between 0.0042 and 0.7446 (Table 3 ). Figure 4 shows the dendrogram obtained from CA for quantitative floral characters. The clustering technique was based on similarity for some morphological traits among the 24 accessions. At 0.0 similarity level, each of the 24 accessions maintained uniqueness. However, at about $30 \%$ similarity level, about seven clusters were identified. At this level (30\%), TPtuland TPtu5 were clustered together, TCgl stood alone and all the TVs were together with the exception of TVsu which clustered with TKgs. Expectedly, only four clusters could be identified at about $70 \%$ similarity level. All the Vigna species (TVal and TVa1173; TVm12 and TVm13; TVr145 and TVr1001) appeared to cluster together at nearly the same similarity level with the exception of Vigna subterranea (TVsu1126 and TVsu1415). Only one accession of Lablab purpureus (TLn29) appeared clustered with the Vigna species at nearly the same similarity level.

\section{Floral characters correlation studies}

Table 4 shows correlation coefficients among five floral characters of the miscellaneous legumes. Calyx lobe length positively and strongly $(\mathrm{P} \leq 0.01)$ correlated with standard petal length $(\mathrm{r}=0.841)$, standard petal width $(\mathrm{r}=0.569)$, peduncle length $(\mathrm{r}=0.830)$ and as well as peduncle length with standard petal length $(r=0.753)$. Number of flower per peduncle $(\mathrm{P} \leq 0.05)$ also correlated with standard petal length $(\mathrm{r}=0.413)$ and there was no negative correlation at any level.

\section{Discussion}

Occurrence of intra and inter variables in the species of many organisms is a surety for evolutionary survival and also a signal for improvement of these species for character of significance. ${ }^{12,13}$ The floral morphological characters (qualitative and quantitative) that were examined in the current study differentiated the twelve species of the 24 accessions of the studied taxa. Variations observed in the qualitative characters depicted different genetic basis for the phenotypic expressions of each trait among the minor legumes studied. The range of differences among species for the quantitative characters has evident by high coefficient of variation in the mean values of the Duncan multiple range test' scores is indicative of wild genetic variability among the studied taxa.

The PCA employed in this study is a multivariate statistical technique of importance for classification of species. ${ }^{2,14}$ The main phenotypic characters, which made significant contribution to detecting variation among the accessions studied, were calyx length, stipule length and numbers of flowers are per peduncle. Agreement of the PCA and CA observed lends credence to the existing variability's

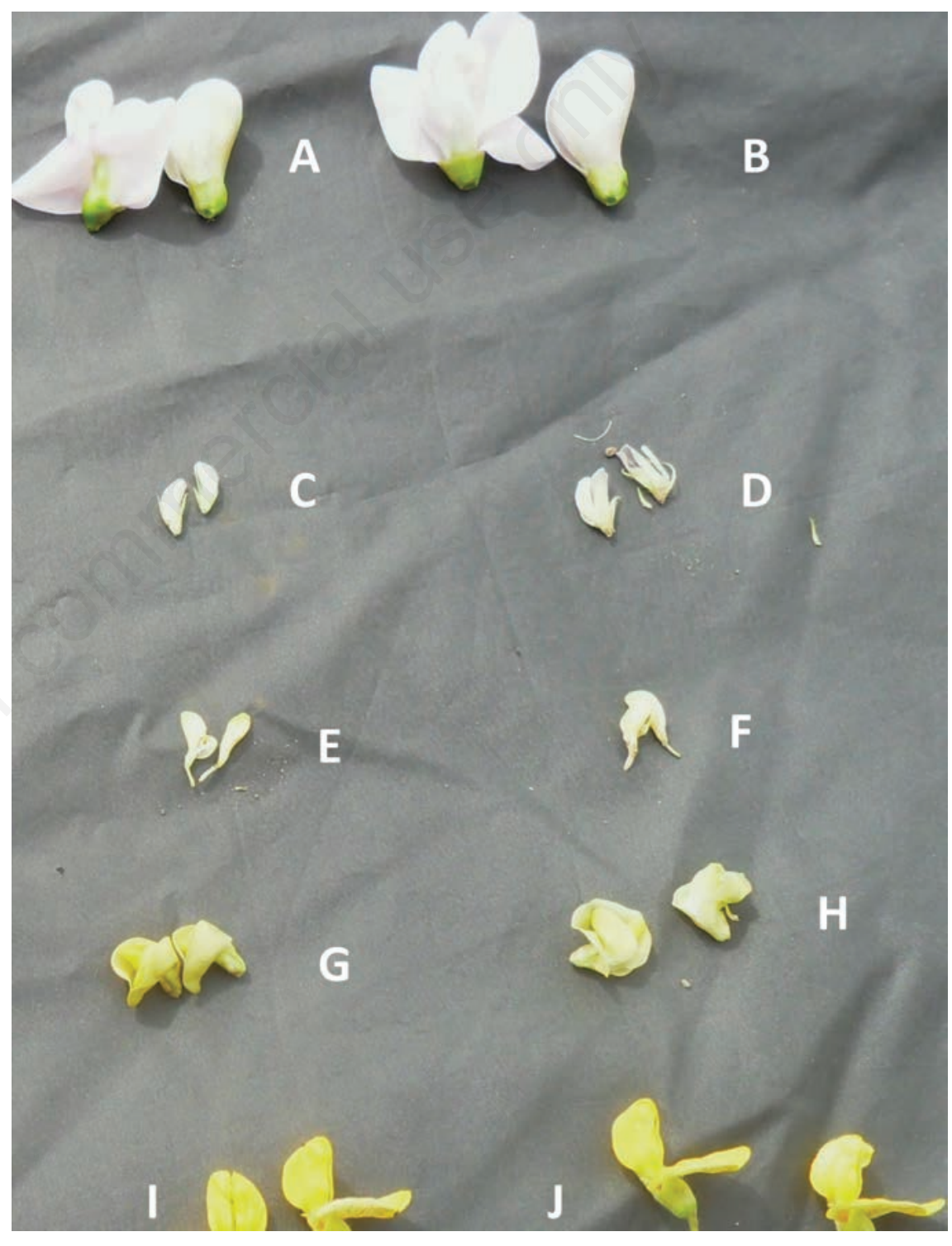

Figure 2. Flower colour of other miscellaneous legumes. A) TSs137, African yam bean; B) TSs156, African yam bean; C) TVSu1126, Bambara groundnut; D) TVSu1415, Bambara groundnut; E) TKg6, Kersting groundnut; F) TKg12, Kersting groundnut; G) TVr145, green gram; H) TVr1001, green gram; I) TCc8127, jack bean; J) TCc8156, jack bean. 
among the minor legumes species and accessions, which is the justice to their classification.

Variabilities revealed in the floral morphological characters were expressed in their reproductive traits such as standard petal length and width, peduncle length, calyx lobe length, flower color and number of flowers per peduncle.

There were indications of more relative intra-specific relatedness as accessions of each species had very close-recorded values for both quantitative and qualitative characters. This is in line with the findings of Adewale. ${ }^{15}$

Psophocarpustetragonolobus and Sphenophylisstenocarpa showed relatively high numbers of flowers per peduncle which is indicative of high floral productivity and hence, high pod and seed yields. This was reflected in Psophocarpustetragonolobus but most of the flowers produced by Sphenophylisstenocarpa were miscarried.

Dendrogram revealed broad groupings, which resulted in fewer groups than the original numbers of the species and accession; this enable and easy logical reference to the studied taxa. Although the passport data of most of the species were not known, the dendrogram

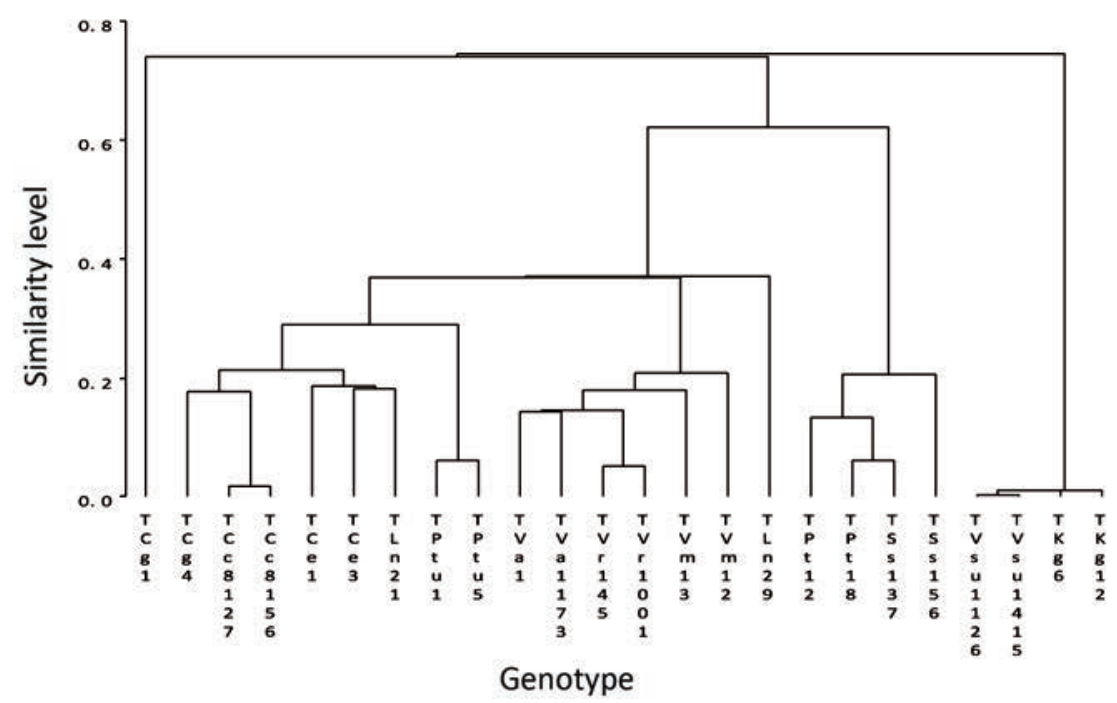

Figure 3. Dendrogram showing grouping of 24 accessions of the miscellaneous legumes based on their quantitative floral characters.

Table 3. Cluster history of the 24 accessions miscellaneous legumes based on their floral characters.

\begin{tabular}{|c|c|c|c|c|}
\hline Morphotypes & Pair & & Rate & Distance \\
\hline 23 & TVsu1126 & TVsul415 & 2 & 0.0042 \\
\hline 22 & CL23 & TKg6 & 3 & 0.0098 \\
\hline 21 & CL22 & TKg12 & 4 & 0.0105 \\
\hline 20 & TCc8127 & TCc8156 & 2 & 0.0177 \\
\hline 19 & TVr145 & TVr1001 & 2 & 0.0512 \\
\hline 18 & TPtul & TPtu5 & 2 & 0.0618 \\
\hline 17 & TPt18 & TSs137 & 2 & 0.0621 \\
\hline 16 & TPt12 & CL17 & 3 & 0.1328 \\
\hline 15 & TVal & TVA1173 & 2 & 0.1423 \\
\hline 14 & CL15 & CL19 & 4 & 0.1461 \\
\hline 13 & $\mathrm{TCg} 4$ & CL20 & 3 & 0.1763 \\
\hline 12 & CL14 & TVm13 & 5 & 0.1806 \\
\hline 11 & TCe3 & TLn21 & 2 & 0.1827 \\
\hline 10 & TCel & CL11 & 3 & 0.1879 \\
\hline 9 & CL16 & TSs 156 & 4 & 0.2064 \\
\hline 8 & CL12 & TVm12 & 6 & 0.2089 \\
\hline 7 & CL13 & CL10 & 6 & 0.2124 \\
\hline 6 & CL7 & CL18 & 8 & 0.2883 \\
\hline 5 & CL6 & CL8 & 14 & 0.3677 \\
\hline 4 & CL5 & TLn29 & 15 & 0.3709 \\
\hline 3 & CL4 & CL9 & 19 & 0.6222 \\
\hline 2 & TCg1 & CL3 & 20 & 0.7395 \\
\hline 1 & CL2 & CL21 & 24 & 0.7446 \\
\hline
\end{tabular}


analysis grouping might have implicated linkage between the sources of species and accessions and the characters exhibited. Both nature and nurture contribute to the phenotypic character of an organism. The observed differences and similarities among the studied taxa were basically genetic, since the influence of the nurture has being removed by raising the plants under the-same environment. Hence, these genetic variations could be utilized as raw materials for genetic improvement.

The result of the floral morphological features of the studied taxa showed some diagnostic characteristics that could be employed for taxonomic decisions. Morphologically, the observed features that separated the species from one another shared relevance with the studies of Okwulechi and Okoli, ${ }^{16}$ and Edeoga and Emeka, ${ }^{17}$ who employed comparative mor- phology of different species in establishing relation among the studied taxa.

\section{Conclusions}

The essence of diversity studies in crop species is to reveal variation and its pattern within the crop's germplasm. Products of such assessments become materials(s) for crop improvement. The current report clearly reveals diversity and phylogeny studies on twenty-four accessions of twelve species of miscellaneous legumes. Values recorded are representative of the genetic variants and overlaps among and within the species of these taxa, and may serve as future reference for other studies in this field.

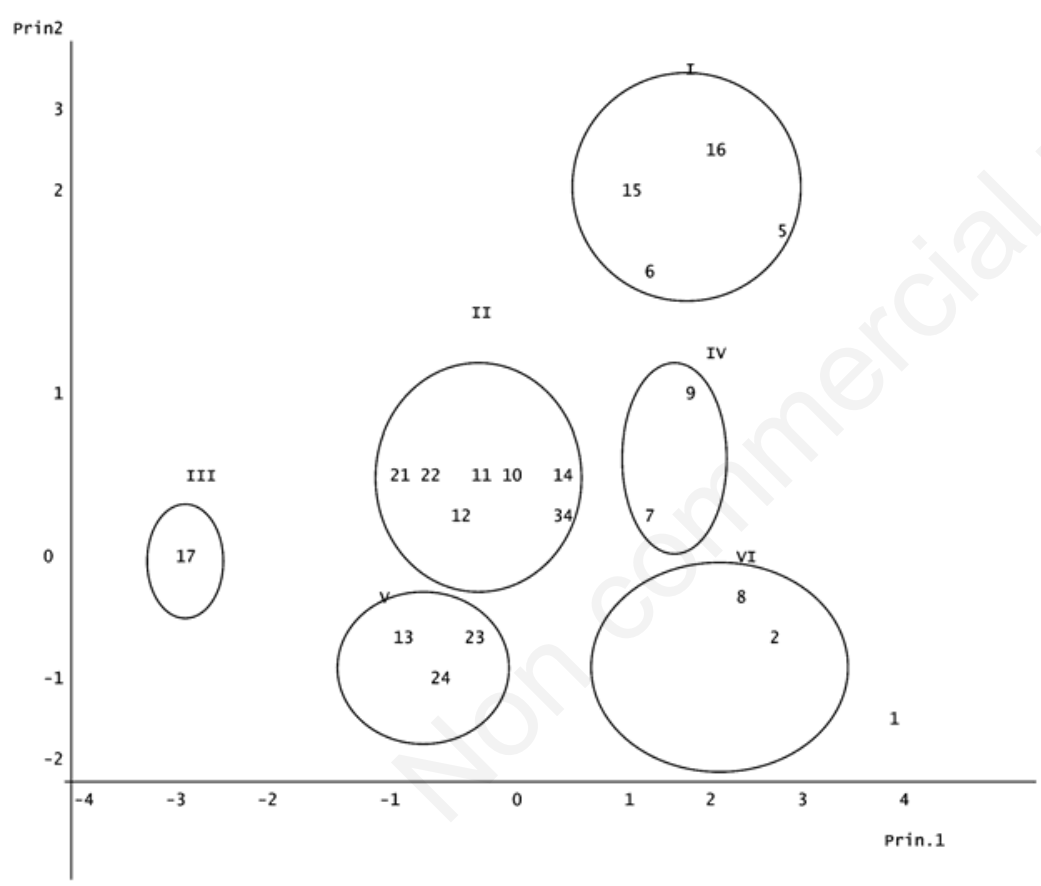

Figure 4. Two dimensional spatial configurations of the twelve species of twenty-four accessions miscellaneous legumes according to their floral characters.

Table 4. Correlation coefficients of five floral characters of the miscellaneous legumes.

\begin{tabular}{lccccc} 
Characters & SPL & SPW & PL & CLL & NFP \\
SPL & 1 & $0.732^{*}$ & $0.753^{*}$ & $0.841^{*}$ & 0.404 \\
SPW & 1 & 0.400 & $0.569^{*}$ & $0.413^{\circ}$ \\
\hline PL & & 1 & $0.830^{*}$ & 0.253 \\
CLL & & & 1 & 0.091 \\
\hline NFP & & & & 1
\end{tabular}

*Correlation is significant at the 0.01 level (2-tailed). ${ }^{\circ}$ Correlation is significant at the 0.05 level (2-tailed). SPL, Standard Petal length; SPW, Standard Petal width; PL, Peduncle length; CLL, Calyx Lobe Length; DSE, Days from sowing to emergence; NFP, Number of Flower of Peduncle.

\section{References}

1. Apyanwu AC. A textbook of agriculture. 1st ed. Nairobi: African Educational Publisher; 1981. pp 103-4.

2. Agbolade J0, Adegbite AE, Olawuyi OJ, et al. Comparative study on the epidermal features of twelve under-utilized legume accessions. SJAS 2011;1:233-40.

3. King HG. Pasture for the South. 4th ed. Dancville: The Inter Estate Printers and Publishers, Inc.; 1963. pp 1-12.

4. Omitogun OG, Okeola OG, Fasidi IO, et al. A galactose-specific lectin from sphenostylisstenocarpais insecticidal against cowpea genetic engineering. ACSS 2001;5:111-6.

5. Aremu MO, Olaofe 0, Akintayo TE. A comparative study on the chemical and amino acid composition of some Nigerian underutilized legume flours. PJN 2006;5:34-8.

6. Aykroyd WR, Doughty JC. Legumes in human nutrition. Nutritional studies No.19. Rome: Food and Agricultural Organization; 1969.

7. Oshodi AA, Ipinmoroti KO, Adeyeye EI, Hall GM. In vitro multienzyme digestability of proteins of six varieties of African Yam Bean Flowers. J Sci Food Agriculture 1995;69:373-7.

8. Akande EA, Odedeji J0, Agbolade J0. Physical characterisation and physicochemical properties of jackbeans (canavalia ensiformis). AJER 2014;2:2302.

9. Adeboye OC. Reducing the oligosaccharide and anti-nutritional factor contents of two under-utilized grain legumes of Southwest Nigeria. Acta Hortic 2009;806:355-60.

10. National Academy of Sciences of the United State of America. Under-utilized legumes. Washington DC: US National Academy of Sciences; 1979.

11. International Plant Genetic Resource Institute. Descriptors for Cowpea. Rome: International Plant Genetic Resource Institute; 1983.

12. Ramanujam S. Genetic diversity, stability and plant type in pulse crops. International Workshop on Grain Legumes 1975. pp 167 76.

13. Chheda HR, Fatokun CA. Numerical taxonomy of variation pattern in Okra (Abelmoschusesculentus (L) Moench). Botan Gaz 1982;143:253-61.

14. Ariyo OJ. Genetic diversity in West Africa Okra (Abelmoschuscaillei) - multivariate analysis of morphological and agronomic characters. Genet Resour Crop Ev 1993;40:25-32.

15. Adewale DB. Genetic diversity, stability and reproductive biology of African Yam Bean, Sphenostylisstenocarpa (Hochst. Ex 
A. Rich) Harms. PhD Thesis. University of Agriculture, Abeokuta, Nigeria. 2010.

16. Okwulehi IC, Okoli BE. Morphological and palynological studies in some species of
Corchorus L. Tiliaceae. New Botanist 1999;25:87-101.

17. Edeoga HO, Emeka AU. Morphology of the leaf epidermis and systematic in some dis- sotis species benth (Melastomataceae) global. J Pure Appl Sci 2000:6:371-4. 